\title{
Ammonificins A and B, Hydroxyethylamine Chroman Derivatives from a Cultured Marine Hydrothermal Vent Bacterium, Thermovibrio ammonificans
}

\author{
Eric H. Andrianasolo ${ }^{\dagger}$, Liti Haramaty ${ }^{\dagger}$, Richard Rosario-Passapera ${ }^{\dagger}$, Kelly Bidle ${ }^{\ddagger}$, Eileen \\ White ${ }^{\S},-\square$, Costantino Vetriani ${ }^{\dagger}$, Paul Falkowski $^{\dagger}$, and Richard Lutz ${ }^{*}, \dagger$ \\ tCenter for Marine Biotechnology, Institute of Marine and Coastal Sciences, Rutgers, The State \\ University of New Jersey, New Jersey 08901-8521 \\ ‡ Department of Biology, Rider University, 2083 Lawrenceville Road, Lawrenceville, New Jersey \\ 08648 \\ $\S$ Center for Advanced Biotechnology and Medicine, Department of Molecular Biology and \\ Biochemistry, Rutgers, The State University of New Jersey, 679 Hoes Lane, Piscataway, New \\ Jersey 08854 \\ ${ }^{\perp}$ Robert Wood Johnson Medical School, University of Medicine and Dentistry of New Jersey, 675 \\ Hoes Lane, Piscataway, New Jersey 08854 \\ $\square$ The Cancer Institute of New Jersey, 195 Little Albany Street, New Brunswick, New Jersey 08903
}

\section{Abstract}

Two hydroxyethylamine chroman derivatives, ammonificins A (1) and B (2), were isolated from the marine hydrothermal vent bacterium Thermovibrio ammonificans. The molecular structures of these compounds were determined using a combination of NMR, mass spectrometry, and CD analyses. Biological activities were determined using an antimicrobial assay and the patented ApopScreen cellbased screen for apoptosis induction and potential anticancer activity. To our knowledge, this is the first report of secondary metabolites from the marine hydrothermal vent bacterium $T$.

ammonificans.

\begin{abstract}
The oceans are Earth's largest ecosystem and hold great, underexplored potential for drug discovery. Within this vast ecosystem, however, one area remains enigmatic: deep-sea hydrothermal vents, which are characterized by high concentrations of reduced sulfur compounds. ${ }^{1}$ Life is supported by the growth of chemolithoautotrophic bacteria, capable of oxidizing hydrogen sulfide, hydrogen, and other reduced inorganic compounds to provide energy that is used to fuel carbon dioxide fixation into macromolecules.

Chemoautotrophic organisms are known to produce chemical defenses against their consumers. Some chemically deterrent species are also known to harbor chemoautotropic endosymbiotic bacteria, and these microbial symbionts may produce metabolites that defend their host species. ${ }^{2}$ In this study we investigated the ability of chemolithoautotrophic bacteria to produce novel secondary metabolites.
\end{abstract}

(C) 2009 American Chemical Society and American Society of Pharmacognosy

“To whom correspondence should be addressed. Tel: (732) 93218959, ext. 242. Fax: (732) 932-6557. rlutz@imcs.marine.rutgers.edu. Supporting Information Available: NMR and MS data of $\mathbf{1}$ and 2. This material is available free of charge via the Internet at http://pubs.acs.org. 


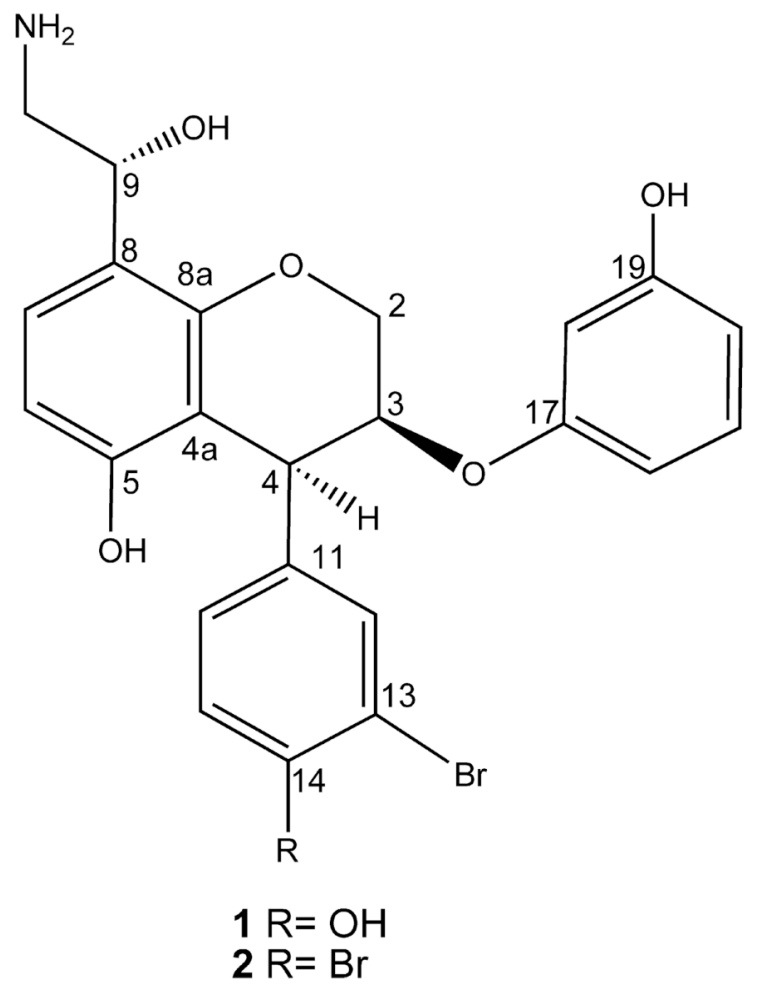

Thermovibrio ammonificans, a thermophilic, anaerobic, chemolithoautotrophic bacterium, was isolated from the walls of an active deep-sea hydrothermal vent chimney on the East Pacific Rise at $9^{\circ} 50^{\prime} \mathrm{N}$. Cells of the organism were Gram-negative, motile rods that were about 1.0 $\mu \mathrm{m}$ in length and $0.6 \mu \mathrm{m}$ in width. Growth occurred between 60 and $80{ }^{\circ} \mathrm{C}$ (optimum at $75^{\circ}$ C), 0.5 and $4.5 \%$ (w/v) $\mathrm{NaCl}$ (optimum at 2\%), and $\mathrm{pH} 5$ and 7 (optimum at 5.5). The generation time under optimal conditions was $1.57 \mathrm{~h}$. Growth occurred under chemolithoautotrophic conditions in the presence of $\mathrm{H}_{2}$ and $\mathrm{CO}_{2}$, with nitrate or sulfur as the electron acceptor and with concomitant formation of ammonium or hydrogen sulfide, respectively. ${ }^{3}$

Forty grams wet weight of the organism was extracted in $\mathrm{MeOH}$. One part of the MeOH soluble extract was dissolved in DMSO and was tested for apoptosis induction as assessed by the ApopScreen protocol. ${ }^{4-6}$ Screening should identify compounds that possess proapoptotic, and potentially anticancer, activity.

The extract induced apoptosis and therefore was fractionated, with subsequent purification by analytical RPHPLC. Using this strategy, two compounds were isolated. The chemical structures of these two compounds (1 and 2) were ascertained by standard spectroscopic techniques, as described below.

The LR ESIMS of ammonificin A (1) displayed ion clusters at $m / z$ 488(100)/490(98), indicating the presence of one bromine. The molecular formula of 1 was established as $\mathrm{C}_{23} \mathrm{H}_{22} \mathrm{BrNO}_{6}$ on the basis of HR ESIMS $\left[\mathrm{m} / \mathrm{z} 488.0701(\mathrm{M}+\mathrm{H})^{+}\right]$. The ${ }^{1} \mathrm{H}$ spectrum of $\mathbf{1}$ indicated clearly the presence of nine aromatic ring signals: $\delta_{\mathrm{H}} 6.67[(\mathrm{~d}, J=7.9 \mathrm{~Hz}), \mathrm{H}-6], 7.09[(\mathrm{~d}, J=7.9 \mathrm{~Hz})$, H-7], $\delta_{\mathrm{H}} 7.41$ [s, H-12], 6.77 [(d, J=7.2 Hz), H-15], 7.26 [(d, J= 7.2 Hz), H-16], 6.65 [s, H-18], 6.74 [(d, $J=7.8 \mathrm{~Hz}), \mathrm{H}-20], 7.01[(\mathrm{dd}, J=7.8 \mathrm{~Hz}, 7.6 \mathrm{~Hz}), \mathrm{H}-21]$, and $6.81[(\mathrm{~d}, J=7.6$ $\mathrm{Hz}), \mathrm{H}-22]$. Their corresponding methine carbons were assigned from multiplicity edited HSQC: C-6 $(\delta 108.0)$, C-7 $(\delta 126.8)$, C-12 $(\delta 133.1)$, C-15 $(\delta 118.4)$, C-16 $(\delta 128.8)$, C-18 $(\delta$ $101.4), \mathrm{C}-20(\delta 107.3), \mathrm{C}-21$ ( $\delta 130.5)$, and C-22 ( $\delta 106.8)$. Analysis of HMBC and multiplicity 
edited HSQC data suggested the presence of nine quaternary carbons characteristic of signals belonging to aromatic ring systems $\left(\delta_{\mathrm{C}} 110.8,116.1,119.7,137.8,155.7,156.9,157.1,157.9\right.$, and 158.9). Given the number of carbons belonging to the aromatic signals, ammonificin A (1) was found to possess three aromatic ring systems. Furthermore, three proton signals characteristic of hydroxy groups attached to aromatic ring systems were present in the ${ }^{1} \mathrm{H}$ spectrum: $\delta_{\mathrm{H}} 8.48$ (br s), 9.26 (br s), and 9.47 (br s). Closer examination of the ${ }^{1} \mathrm{H}-{ }^{1} \mathrm{H}$ COSY along with the ${ }^{1} \mathrm{H}$ NMR spectrum suggested the presence of signals characteristic of a dihydropyran moiety: $\delta_{\mathrm{H}} 4.35$ [(d, $\left.\left.J=5.6 \mathrm{~Hz}\right), \mathrm{H}-4\right], 4.98$ [m, H-3], and 4.45 [m, H-2]. HMBC correlations between H-6 and C-7 $\left(\delta_{\mathrm{C}} 126.8\right), \mathrm{C}-5\left(\delta_{\mathrm{C}} 155.7\right), \mathrm{C}-4 \mathrm{a}\left(\delta_{\mathrm{C}} 116.1\right)$; H-7 and C-8 $\left(\delta_{\mathrm{C}} 119.7\right), \mathrm{C}-8 \mathrm{a}\left(\delta_{\mathrm{C}} 157.9\right) ; \mathrm{H}-4$ and $\mathrm{C}-4 \mathrm{a}\left(\delta_{\mathrm{C}} 116.1\right)$; and $\mathrm{H}-2$ and $\mathrm{C}-8 \mathrm{a}\left(\delta_{\mathrm{C}} 157.9\right)$ strongly suggested that 1 has a chroman moiety in its structure. Another interesting group resulting from the ${ }^{1} \mathrm{H}-{ }^{1} \mathrm{H}$ COSY analysis is a hydroxyethylamine moiety ${ }^{14}$ in $1: \delta_{\mathrm{H}} 4.70[\mathrm{~m}, \mathrm{H}-9]$ and 3.45 [m, H-10]. Moreover, this hydroxyethylamine moiety is found to be attached to $\mathrm{C}-8$ according to the HMBC correlation between $\mathrm{H}-9$ and $\mathrm{C}-8\left(\delta_{\mathrm{C}} 119.7\right)$. The two remaining aromatic rings were established using ${ }^{1} \mathrm{H}-{ }^{1} \mathrm{H}$ COSY and $\mathrm{HMBC}$ correlations (Figure 1). The ${ }^{1} \mathrm{H}-{ }^{1} \mathrm{H}$ COSY correlation between $\mathrm{H}-15$ and $\mathrm{H}-16, \mathrm{HMBC}$ correlations between $\mathrm{H}-15$ and C-11, C-13, C-14, C-16, and HMBC correlations between $\mathrm{H}-12$ and C-13, C-14, C-16 define a trisubstituted aromatic ring system. The ${ }^{1} \mathrm{H}-{ }^{1} \mathrm{H}$ COSY correlations between $\mathrm{H}-21$ and $\mathrm{H}-20, \mathrm{H}-22$ and $\mathrm{HMBC}$ correlations between $\mathrm{H}-20$ and C-19, C-22 and between H-22 and C-17, C-18, C-20 generated a disubstituted aromatic ring system. The connectivity between the chroman moiety and the remaining two ring systems was established by HMBC correlations: $\mathrm{H}-4$ to $\mathrm{C}-12, \mathrm{C}-16$ and $\mathrm{H}-3$ to $\mathrm{C}-17$. The chemical shifts of the quaternary carbons belonging to the aromatic ring systems played an important role in the assignment of the regiochemistry. For example, the chemical shift of the C-5 quaternary carbon $\left(\delta_{C} 155.7\right)$ indicated that hydroxy was attached, whereas the shift at the $\mathrm{C}-13$ quaternary carbon $\left(\delta_{\mathrm{C}} 110.8\right)$ indicated bromine was present. Similarly, the chemical shifts at C-14 $\left(\delta_{C} 157.1\right)$ and C-19 $\left(\delta_{C} 156.9\right)$ indicated that hydroxys were attached to these positions.

To determine the absolute configurations at C-3, C-4, and C-9, a circular dichroism (CD) spectrum of ammonificin A (1) was obtained. This experimental CD spectrum was then compared to the predicted CD spectra of all possible stereoisomers. Eight stereoisomers are possible for ammonificin A (1). The coupling constant between $\mathrm{H}-3$ and $\mathrm{H}-4(J=5.6 \mathrm{~Hz})$ suggested a cis relationship between these two protons (H-3 equatorial, $\mathrm{H}-4$ axial), which indicated only four probable stereoisomers: $(3 S, 4 S, 9 R),(3 S, 4 S, 9 S),(3 R, 4 R, 9 R),(3 R, 4 R$, $9 S)$.

These four probable stereoisomers were submitted to geometry optimization by the DFT (BLYP/6-31G*) approach. ${ }^{7}$ For each minimized geometry a single CD spectrum was calculated using the TDDFT approach (B3LYP/TZVP). 7 The overall CD spectra thus obtained were subsequently UV-corrected and compared with the experimental one of $\mathbf{1}$. An excellent agreement between the CD curve calculated for $3 S, 4 S, 9 R$ and the experimental was found (Figure 2). This indicated that $\mathbf{1}$ has the configuration $3 S, 4 S, 9 R$, and the structure of $\mathbf{1}$ is established as shown.

The LR ESIMS of ammonificin B (2) displayed ion clusters at $\mathrm{m} / \mathrm{z}$ 550(51)/552(100)/554(48), indicating the presence of two bromines. The molecular formula of $\mathbf{2}$ was established as $\mathrm{C}_{23} \mathrm{H}_{21} \mathrm{Br}_{2} \mathrm{NO}_{5}$ on the basis of HR ESIMS $\left[\mathrm{m} / z 549.9857(\mathrm{M}+\mathrm{H})^{+}\right]$. The molecular formula of 2 showed that it has one more bromine atom and one less hydrogen and oxygen atom compared to 1 .

The strong similarity of its ${ }^{1} \mathrm{H}$ NMR spectrum to that of ammonificin A (1) revealed that $\mathbf{1}$ and 2 share the same general structural features. Furthermore, only two proton signals characteristic of hydroxy groups attached to the aromatic ring system were present in the ${ }^{1} \mathrm{H}$ spectrum of 2 
$\left(\delta_{\mathrm{H}} 9.27\right.$ (br s), 9.46 (br s)), suggesting that one hydroxy group was replaced by one bromine atom. HMBC correlations between $\mathrm{H}-16$ and $\mathrm{C}-14$ and also between $\mathrm{H}-12$ and C-14 confirmed this suggestion. From the above analyses, it was concluded that the structure of $\mathbf{2}$ is similar to that of 1 except that the hydroxy group attached to $\mathrm{C}-14$ was replaced by one bromine atom. The absolute configurations at C-3, C-4, and C-9 of ammonificin B (2) were ascertained by the same methods as described above. Although chroman derivatives are known structures, the co-occurrence of hydroxyethylamine and phenol in $\mathbf{1}$ or brominated phenol in $\mathbf{2}$ with chroman is unique.

The isolated compounds were evaluated in the apoptosis induction assay and with antimicrobial tests, but the results were inconclusive due to the presence of minor inseparable impurities. The original extract showed interesting activity; however pure compounds that correlated with the activity were not obtained. The minor components that could not be removed during the purification process probably have similar structure and polarity to $\mathbf{1}$ and $\mathbf{2}$. An effort to scale up the culture and reisolate ammonificins $\mathrm{A}$ and $\mathrm{B}$ as well as the minor components of the extract is still in progress. The compounds described herein represent new chemical structures and may have potential in future drug discovery efforts.

\section{Experimental Section}

\section{General Experimental Procedures}

Optical rotations were measured on a JASCO P 1010 polarimeter. UV and FT-IR spectra were obtained employing Hewlett-Packard 8452A and Nicolet 510 instruments, respectively. CD spectra were acquired on a JASCO J-720 spectropolarimeter. All NMR spectra were recorded on a Bruker Avance DRX400 spectrometer, Varian-400 instrument (400 MHz), and Varian-500 instrument (500 MHz). Spectra were referenced to residual solvent signals with resonances at $\delta_{\mathrm{H} / \mathrm{C}} 2.50 / 39.51\left(\mathrm{DMSO}-d_{6}\right)$. ESIMS data were acquired on a Waters Micromass LCT Classic mass spectrometer and Varian 500-MS LC ion trap. HPLC separations were performed using Waters 510 HPLC pumps, a Waters 717 plus autosampler, and a Waters 996 photodiode array detector. All solvents were purchased as HPLC grade.

\section{Extraction and Isolation Procedures}

Cell Culturing-Thermovibrio ammonificans was routinely grown in modified SME medium as previously described. ${ }^{3}$ For the purpose of this study, bacterial cells were harvested from a total of $5 \mathrm{~L}$ of bacterial culture.

The material ( $40 \mathrm{~g}$ ) was extracted three times with $\mathrm{MeOH}$ to give a polar crude organic extract $(550 \mathrm{mg})$. A portion of this extract $(20 \mathrm{mg})$ was tested for apoptosis induction. The crude organic extract was found active and subjected to fractionation using a solid-phase extraction cartridge (normal-phase silica) to give four fractions, F1 to F4, using hexane, hexane-EtOH, $\mathrm{EtOH}$, and $\mathrm{MeOH}$ as an increasingly hydrophilic solvent system series. The fractions eluting with hexane-EtOH (F2) and $\mathrm{MeOH}(\mathrm{F} 4)$ had apoptosis induction activity. These fractions were further chromatographed on analytical RP HPLC (Phenomenex Luna C18, $250 \times 4.60 \mathrm{~mm}$ ) using isocratic elution with $50 \% \mathrm{MeOH}$ and $50 \% \mathrm{H}_{2} \mathrm{O}$ (flow rate $1 \mathrm{~mL} / \mathrm{min}$ ) to yield $3 \mathrm{mg}$ of $\mathbf{1}\left(t_{\mathrm{R}}=2.8 \mathrm{~min}\right)$ from $\mathrm{F} 2$, and $1.6 \mathrm{mg}$ of $\mathbf{2}\left(t_{\mathrm{R}}=4.4 \mathrm{~min}\right)$ from $\mathrm{F} 4$.

Computational Methods-Geometry optimization and UV and CD computations were undertaken using TDDFT with the B3LYP hybrid functional and a TZVP basis set, as included in the TURBOMOLE suite of programs with TmoleX, a graphical user interface to the Turbomole quantum chemistry program package. ${ }^{7}$ The corresponding oscillator and rotatory strengths thus obtained were summed and energetically weighted, following the Boltzmann statistics. Finally, the overall UV and CD spectra were simulated as sums of Gaussian functions 
centered at the wavelengths of the respective electronic transitions and multiplied by the corresponding oscillator or rotatory strengths, transformed into absorption and $\Delta \varepsilon$ values, respectively. ${ }^{8-11}$

Biological Evaluation: Apoptosis Induction-Apoptosis induction in the presence of compounds $\mathbf{1}$ and $\mathbf{2}$ was carried out as described in Andrianasolo et al. 2007 using the ApoScreen assay. ${ }^{\cdot} 15^{-} 18$ In this assay viability of treated W2 (apoptosis competent) and D3 (apoptosis defective) 12 cells is measured using a modification of the MTT assay.13 For this study, viability was measured at 0 and $48 \mathrm{~h}$, and differential growth was calculated in the presence of the compounds staurosporine (an apoptosis inducer) as positive control and DMSO as negative controls.

Ammonificin A (1): $[\alpha]^{24}{ }^{-150}(\mathrm{c} 0.8, \mathrm{MeOH}) ; \mathrm{UV}(\mathrm{EtOH}) \lambda_{\max }(\log \varepsilon) 267$ (2.90), 285 (3.68), 305 (3.70); CD (EtOH) see Figure 2; IR $v_{\max }$ (neat) 3350, 2950, 1620, 1460, 1380, 1230, 1160, 1120, 1090, 1020, $805 \mathrm{~cm}^{-1} ;{ }^{1} \mathrm{H}$ NMR and ${ }^{13} \mathrm{C}$ NMR, see Table 2; HR ESIMS $\left[\mathrm{m} / z\right.$ 488.0701 $(\mathrm{M}+\mathrm{H})^{+}\left(\right.$calcd for $\left.\left.\mathrm{C}_{23} \mathrm{H}_{23} \mathrm{BrNO}_{6}, 488.0709\right)\right]$.

Ammonificin B (2): $[\alpha]{ }^{24}{ }_{\mathrm{D}}-150$ ( $c$ 0.8, MeOH); UV (EtOH) $\lambda_{\max }(\log \varepsilon) 267$ (2.90), 285 (3.68), 305 (3.65); CD (EtOH) see Figure 3; IR $v_{\max }$ (neat) 3350, 2950, 1620, 1460, 1380, 1230, 1160, 1120, 1090, 1020, $805 \mathrm{~cm}^{-1} ;{ }^{1} \mathrm{H}$ NMR and ${ }^{13} \mathrm{C}$ NMR, see Table 2; HR ESIMS $\left[\mathrm{m} / \mathrm{z} 549.9857(\mathrm{M}+\mathrm{H})^{+}\right.$(calcd for $\left.\left.\mathrm{C}_{23} \mathrm{H}_{22} \mathrm{Br}_{2} \mathrm{NO}_{5}, 549.9865\right)\right]$.

\section{Supplementary Material}

Refer to Web version on PubMed Central for supplementary material.

\section{Acknowledgments}

We thank K. McPhail and S. Kim for NMR data from NMR facilities at Oregon State University and Department of Chemistry at Rutgers University, respectively. We also thank H. Zheng for mass spectrometry analyses at the Center for Advanced Biotechnology and Medicine, Rutgers University. This research was funded by Rutgers University through an Academic Excellence award, by NSF grants OCE 03-27373 (R.A.L and C.V.) and MCB 04-56676 (C.V.), by the New Jersey Agricultural and Experiment Station (C.V.), and by NIH grant R37 CA53370 (E.W.).

\section{References and Notes}

1. Gärtner A, Wiese J, Imhoff JF. Int. J. Syst. Evol. Microbiol 2008;58:34-39. [PubMed: 18175678]

2. Kicklighter CE, Fisher CR, Hay ME. Mar. Ecol.: Prog. Ser 2004;275:11-19.

3. Vetriani C, Speck MD, Ellor SV, Lutz RA, Starovoytov V. Int. J. Syst. Evol. Microbiol 2004;54:175181. [PubMed: 14742477]

4. Andrianasolo EH, Haramaty L, Degenhardt K, Mathew R, White E, Lutz R, Falkowski P. J. Nat. Prod 2007;70:1551-1557. [PubMed: 17900165]

5. Mathew R, Degenhart K, Haramaty L, Karp CM, White E. Methods Enzymol. 2008

6. Karantza-Wadsworth, V.; White, E. Progammed Cell Death. Cancer: Principles and Practice of Oncology. DeVita, VT.; Lawrence, TS.; Rosenberg, SA., editors. Philadelphia, PA: Lippincott, Williams, and Wilkins; 2008. in press.

7. Ahlrichs R, Furche F, Hättig C, Klopper W, Sierka M, Weigend F. TURBOMOLE 5.10. 2008

8. Holscher D, Reichert M, Gorls H, Ohlenschlager O, Bringmann G, Schneider B. J. Nat. Prod 2006;69:1614-1617. [PubMed: 17125232]

9. Pecul M, Ruud K, Helgaker T. Chem. Phys. Lett 2004;388:110-119.

10. Diedrich C, Grimme S. J. Phys. Chem 2003;107:2524-2539.

11. Antus S, Kurtan T, Juhász L, Kiss L, Hollósi M, Májer ZS. Chirality 2001;13:493-506. [PubMed: 11466774] 
12. Degenhardt KSR, Chen G, Lindsten T, Thomson C, White E. J. Biol. Chem 2002;277:14127-14134. [PubMed: 11836241]

13. Denyer SP, Maillard J-Y. J. Immunol. Methods 1983;65:55-63. [PubMed: 6606682]

14. Fahy E, Potts BCM, Faulkner J. J. Nat. Prod 1991;54:564-569.

15. Danial N, Korsmeyer S. Cell 2004;116:205-219. [PubMed: 14744432]

16. Gelinas C, White E. Genes Dev 2005;19:1263-1268. [PubMed: 15937216]

17. Degenhardt K, White E. Clin. Cancer Res 2006;12:5274-5276. [PubMed: 17000659]

18. Fesik SW. Nat. Rev. Cancer 2005;5:876-885. [PubMed: 16239906] 


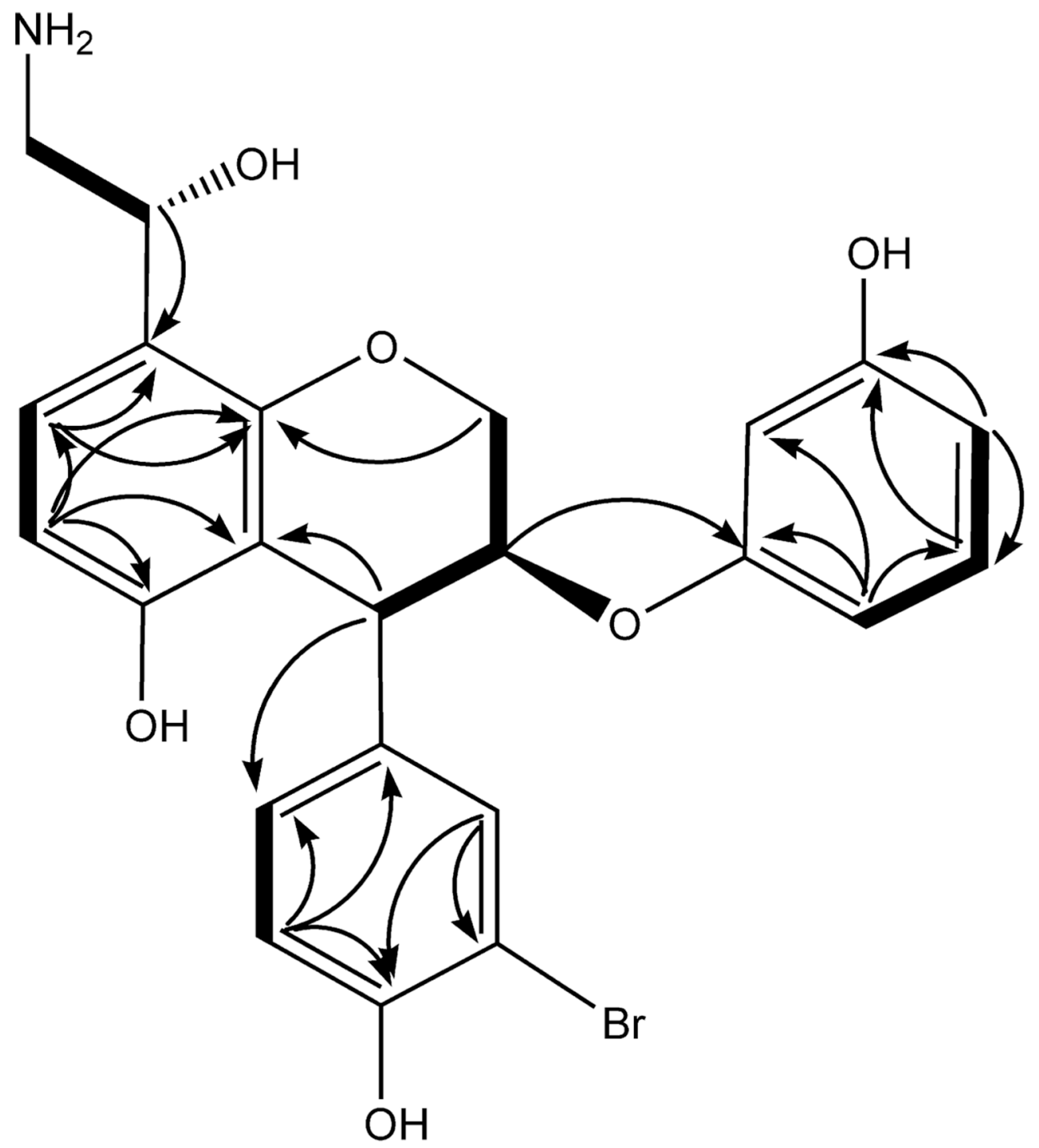

\section{COSY Correlations}

\section{$\rightleftharpoons$ HMBC Correlations}

Figure 1.

Key HMBC and selected COSY correlations for ammonificin A (1). 


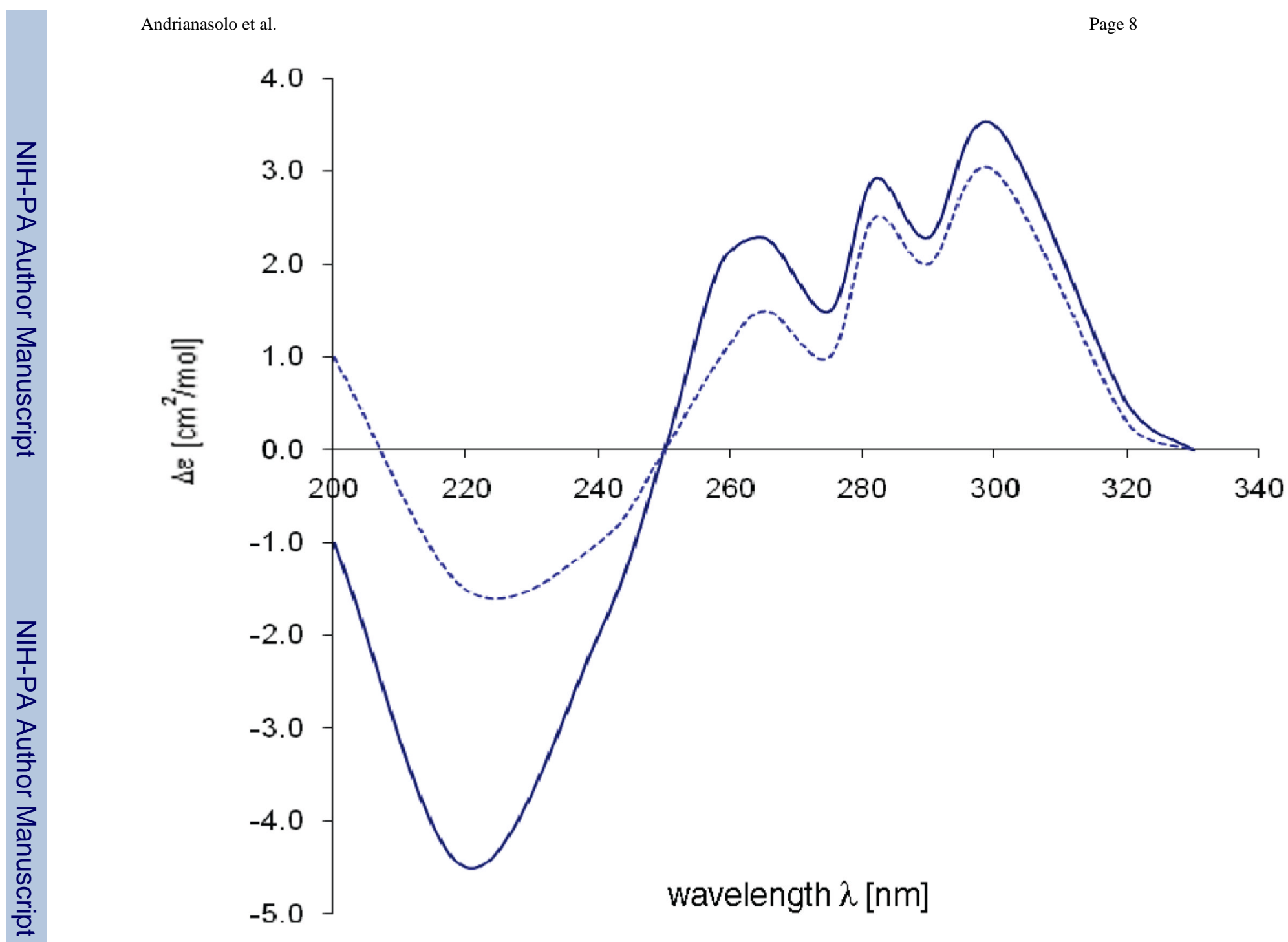

Figure 2.

Comparison of the experimental CD spectrum (-) of $\mathbf{1}$ with the spectra calculated $(\bullet \bullet)$ for 3S, 4S,9R. 


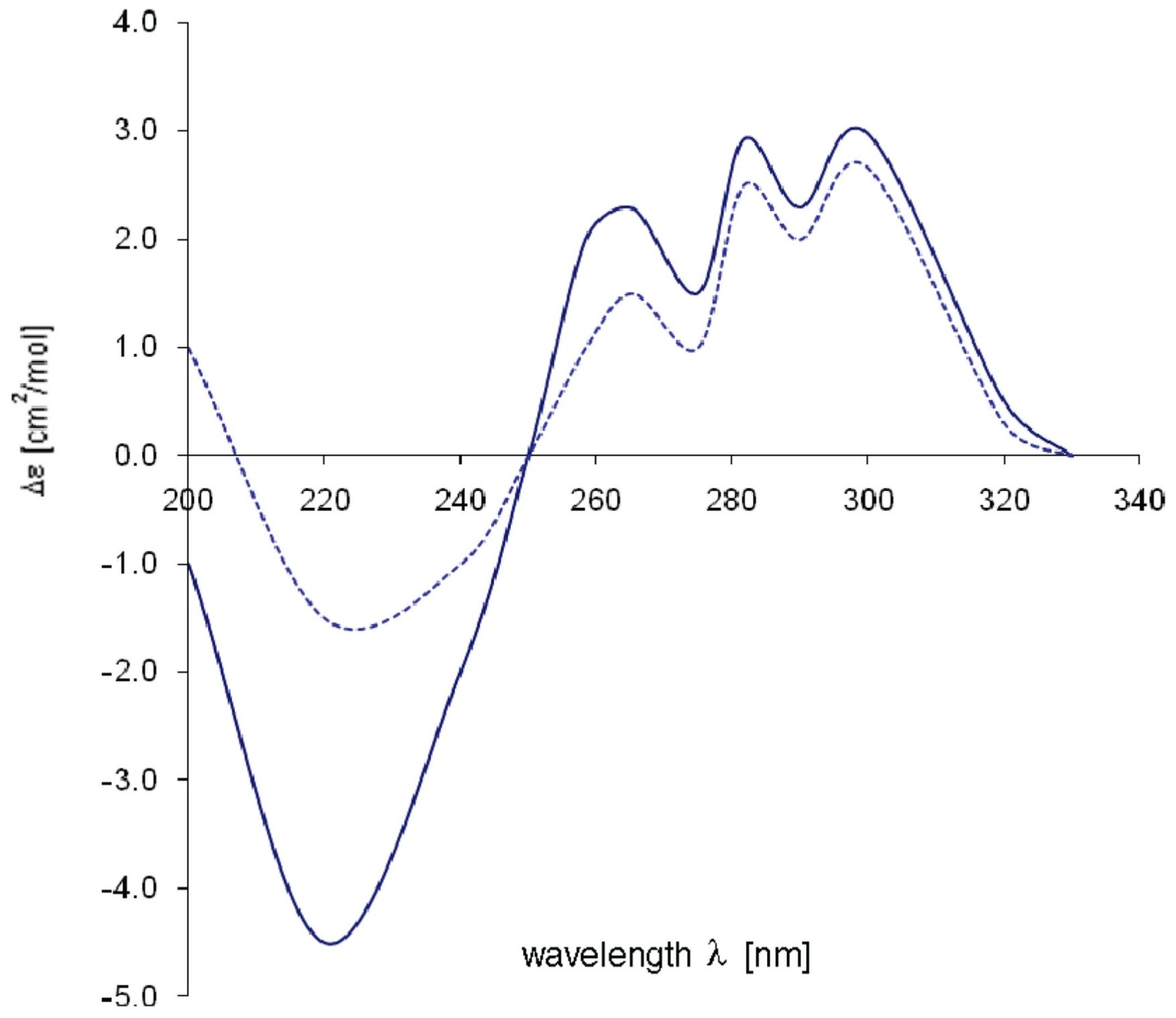

Figure 3.

Comparison of the experimental CD spectrum (-) of $\mathbf{2}$ with the spectra calculated ( $\bullet \bullet \cdot)$ for $3 S, 4 S, 9 R$. 
Table 1.

NMR Spectroscopic Data of Ammonificin A (1) (400 MHz, DMSO-d $d_{6}$ )

\begin{tabular}{|c|c|c|c|}
\hline position & $\boldsymbol{\delta}_{\mathrm{C}}$ & $\delta_{\mathrm{H}}$ & HМBC $^{a}$ \\
\hline 2 & $70.2, \mathrm{CH}_{2}$ & $4.45, \mathrm{~m}$ & $8 \mathrm{a}, 4$ \\
\hline 3 & $83.3, \mathrm{CH}$ & $4.98, \mathrm{~m}$ & 17 \\
\hline 4 & $27.5, \mathrm{CH}$ & $4.35, \mathrm{~d}(5.6)$ & $4 a, 12,16$ \\
\hline $4 a$ & 116.1, qC & & \\
\hline 5 & 155.7, qC & & \\
\hline 6 & $108.0, \mathrm{CH}$ & $6.67, \mathrm{~d}(7.9)$ & $4 a, 5,7,8 \mathrm{a}$ \\
\hline 7 & $126.8, \mathrm{CH}$ & 7.09, d (7.9) & $5,8,8 \mathrm{a}$ \\
\hline 8 & 119.7, qC & & \\
\hline $8 \mathrm{a}$ & 157.9, qC & & \\
\hline 9 & $69.6, \mathrm{CH}$ & $4.70, \mathrm{~m}$ & 7,8 \\
\hline 10 & $49.2, \mathrm{CH}_{2}$ & $3.45, \mathrm{~m}$ & 8,9 \\
\hline 11 & $137.8, \mathrm{qC}$ & & \\
\hline 12 & $133.1, \mathrm{CH}$ & $7.30, \mathrm{~s}$ & $11,13,14,16$ \\
\hline 13 & $110.8, \mathrm{qC}$ & & \\
\hline 14 & 157.1, qC & & \\
\hline 15 & $118.4, \mathrm{CH}$ & $6.77, \mathrm{~d}(7.2)$ & $11,13,14,16$ \\
\hline 16 & $128.8, \mathrm{CH}$ & $7.26, \mathrm{~d}(7.2)$ & $11,12,14,15$ \\
\hline 17 & 158.9, qC & & \\
\hline 18 & $101.4, \mathrm{CH}$ & $6.65, \mathrm{~s}$ & $17,19,20,22$ \\
\hline 19 & 156.9, qC & & \\
\hline 20 & 107.3, CH & $6.74, \mathrm{~d}(7.8)$ & $18,19,21,22$ \\
\hline 21 & $130.5, \mathrm{CH}$ & 7.01, dd $(7.6,7.8)$ & $17,19,20,22$ \\
\hline 22 & $106.8, \mathrm{CH}$ & $6.81, \mathrm{~d}(7.6)$ & $17,18,20,21$ \\
\hline $\mathrm{OH}$ on $\mathrm{C}-5$ & & 9.26, br s & \\
\hline $\mathrm{OH}$ on $\mathrm{C}-14$ & & 8.48, br s & \\
\hline OH on C-19 & & 9.47 , br s & \\
\hline
\end{tabular}

${ }^{a} \mathrm{HMBC}$ correlations, optimized for $8 \mathrm{~Hz}$, are from proton(s) stated to the indicated carbon. 
Table 2.

NMR Spectroscopic Data of Ammonificin B (2) (400 MHz, DMSO- $d_{6}$ )

\begin{tabular}{|c|c|c|c|}
\hline position & $\boldsymbol{\delta}_{\mathbf{C}}$ & $\boldsymbol{\delta}_{\mathbf{H}}$ & HMBC $^{a}$ \\
\hline 2 & $70.2, \mathrm{CH}_{2}$ & $4.45, \mathrm{~m}$ & $8 \mathrm{a}, 4$ \\
\hline 3 & $83.3, \mathrm{CH}$ & $4.98, \mathrm{~m}$ & 17 \\
\hline 4 & $27.5, \mathrm{CH}$ & $4.35, \mathrm{~d}(5.6)$ & $4 a, 12,16$ \\
\hline $4 \mathrm{a}$ & 116.1, qC & & \\
\hline 5 & $155.7, \mathrm{qC}$ & & \\
\hline 6 & $108.0, \mathrm{CH}$ & $6.67, \mathrm{~d}(7.9)$ & $4 \mathrm{a}, 5,7,8 \mathrm{a}$ \\
\hline 7 & $126.8, \mathrm{CH}$ & $7.09, \mathrm{~d}(7.9)$ & $5,8,8 \mathrm{a}$ \\
\hline 8 & $119.7, \mathrm{qC}$ & & \\
\hline $8 \mathrm{a}$ & $157.9, \mathrm{qC}$ & & \\
\hline 9 & $69.6, \mathrm{CH}$ & $4.70, \mathrm{~m}$ & 7,8 \\
\hline 10 & $49.2, \mathrm{CH}_{2}$ & $3.45, \mathrm{~m}$ & 8,9 \\
\hline 11 & $144.2, \mathrm{qC}$ & & \\
\hline 12 & $133.9, \mathrm{CH}$ & $7.30, \mathrm{~s}$ & $11,13,14,16$ \\
\hline 13 & $126.9, \mathrm{qC}$ & & \\
\hline 14 & $123.9, \mathrm{qC}$ & & \\
\hline 15 & $132.5, \mathrm{CH}$ & $7.32, \mathrm{~d}(7.2)$ & $11,13,14,16$ \\
\hline 16 & $129.6, \mathrm{CH}$ & $7.28, \mathrm{~d}(7.2)$ & $11,12,14,15$ \\
\hline 17 & $158.9, \mathrm{qC}$ & & \\
\hline 18 & $101.4, \mathrm{CH}$ & $6.65, \mathrm{~s}$ & $17,19,20,22$ \\
\hline 19 & $156.9, \mathrm{qC}$ & & \\
\hline 20 & 107.3, CH & $6.74, \mathrm{~d}(7.8)$ & $18,19,21,22$ \\
\hline 21 & $130.5, \mathrm{CH}$ & $7.01, \mathrm{dd}(7.6,7.8)$ & $17,19,20,22$ \\
\hline 22 & $106.8, \mathrm{CH}$ & $6.81, \mathrm{~d}(7.6)$ & $17,18,20,21$ \\
\hline $\mathrm{OH}$ on $\mathrm{C}-5$ & & 9.26, br s & \\
\hline $\mathrm{OH}$ on $\mathrm{C}-19$ & & 9.47 , br s & \\
\hline
\end{tabular}

${ }^{a} \mathrm{HMBC}$ correlations, optimized for $8 \mathrm{~Hz}$, are from proton(s) stated to the indicated carbon. 